\title{
Article \\ The Recent Occurrence of Biotic Postharvest Diseases of Apples in Poland
}

\author{
Hubert Głos *D, Hanna Bryk, Monika Michalecka (D) and Joanna Puławska (D)
}

The National Institute of Horticultural Research, Konstytucji 3 Maja 1/3, 96-100 Skierniewice, Poland; hanna.bryk@inhort.pl (H.B.); monika.michalecka@inhort.pl (M.M.); joanna.pulawska@inhort.pl (J.P.)

* Correspondence: hubert.glos@inhort.pl

\begin{abstract}
For the years 2012-2018, we investigated the occurrence of storage diseases caused by fungi on four cultivars of apples grown in the central part of Poland. The fruits were picked in orchards managed with Integrated Pest Management (IPM) practices and stored in a cold room for 5-7 months. Depending on the season, apple cultivar and localization of orchard, the incidence of diseases was different. On apple cvs "Gala", "Ligol" and "Golden Delicious", bull's eye rot (Neofabraea spp.) was the most frequently observed disease, whereas on apple cv. "Gloster", gray mold (Botrytis cinerea) predominated. The blue mold (Penicillium expansum), brown rot (Monilinia spp.) and fungi of Alternaria spp. occurred at significantly lower intensity. We detected the occurrence of the new storage diseases of apples caused by Colletotrichum spp., Neonectria ditissima and Diaporthe eres.
\end{abstract}

Keywords: post-harvest diseases; fungi; apples; cultivars; storage

\section{Introduction}

For many years, Poland has been a leader in apple production in the EU (4 million

Citation: Głos, H.; Bryk, H.; Michalecka, M.; Puławska, J. The Recent Occurrence of Biotic Postharvest Diseases of Apples in Poland. Agronomy 2022, 12, 399. https://doi.org/10.3390/ agronomy12020399

Academic Editor: Renaud Travadon

Received: 23 December 2021

Accepted: 2 February 2022

Published: 5 February 2022

Publisher's Note: MDPI stays neutral with regard to jurisdictional claims in published maps and institutional affiliations.

Copyright: (C) 2022 by the authors. Licensee MDPI, Basel, Switzerland. This article is an open access article distributed under the terms and conditions of the Creative Commons Attribution (CC BY) license (https:// creativecommons.org/licenses/by/ $4.0 /)$. tons in 2021). It is ranked third in the world in terms of apple production after the USA and China. New fruit-storing technologies allow the storage of apples for up to 12 months [1]. An effect of long periods of storage is the occurrence of diseases, both of biotic and abiotic origin, which can also cause a significant loss of fruit. This reduces the profitability of apple production $[2,3]$.

Diseases of biotic origin are mainly caused by fungi. There are more than 90 species of fungi causing the post-harvest diseases described [4], but their occurrence and importance differ from year to year and depend on the cultivation region, climate, cultivar, technology of production, and storage of the fruit. Storage diseases are a consequence of fruit infection that occurs during the growing season and initially remains quiescent until fruit maturation, or infection by injuries (skin damage) that occur before harvesting, during harvesting, or during marketing of fruit [5]. The main factors determining the occurrence of diseases are the presence in the orchard of the source of infection, susceptibility of apple varieties, and weather conditions that favor the development of fungi [6].

In Poland, in the 1950s, the most common apple storage diseases were blue mold (Penicillium expansum Link.) and brown rot Monilinia fructigena (Aderh. Et Ruhl.) Honey) [7]. At this time, studies were conducted on apple cvs "Antonówka", "Queen Renet", "Emperor Wilhelm", and "Wealthy", and the fruits were stored in primitive conditions (cellars, storage rooms). In the 1960s, bitter rot of apples was reported, and the fungus causing the disease was Gloeosporium spp. [8]. In later years, when the cultivars "Gala", "Szampion", "Ligol", and "Golden Delicious" were commonly grown, this disease posed the greatest threat for stored apples [9], whereas gray mold (Botrytis cinerea Pers.) caused large losses on apples of cvs. "Gloster", "Elstar", and "Gala". Moreover, blue mold and brown rot were not a major problem at that time in Poland $[9,10]$.

Bull's eye rot, caused by fungi from the genus Neofabraea (former name Pezicula), is also found in many European countries, such as Germany [11], France [12], and Italy [13], 
and in the northwestern states of the USA [14], some parts of Canada [15], Chile [16], and Australia [17]. Numerous studies were conducted to identify the causal agents of the disease $[15,16,18]$. In Poland, studies showed that Neofabraea alba is the predominant disease-causing species, N. perennans is much less frequent, and N. kienholzii is sporadic [19].

In addition to these four most-important diseases of apples (bull's eye rot, gray mold, blue mold, and brown rot) other apple storage diseases also occur. In the last few years, in some European countries, the incidence of anthracnose caused by fungi from the genus Colletotrichum spp. has been observed [11,12,20]. In the years 2012-2017, new apple pathogens such as Fibulorhizoctonia psychrophila, Fusarium avenaceum, Colletotrichum godetiae, and Truncatella angustata were found in the Netherlands. Only the first of these species was very common, whereas the others were found sporadically [21]. In the USA, new problems of apple rot are due to Sphaeropsis pyriputrescens and Phacidiopycnis washingtonensis [22].

Identifying the causal agents and determining the diseases that affect stored apples is necessary to develop an effective means to control them, and consequently reduce economic losses.

The aim of this study was to evaluate the type and incidence of biotic diseases occurring on apples of several cultivars stored in Poland: "Gala", "Ligol", "Gloster", and "Golden Delicious".

\section{Materials and Methods}

\subsection{Monitoring and Sample Collection}

The studies were carried out during six storage seasons (2012-2018) on apples of four commonly cultivated varieties, stored in a cold room. Fruits were picked in orchards located in Central Poland (Dabrowice (orchard A; 51 $54^{\prime} 52.5^{\prime \prime} \mathrm{N}, 20^{\circ} 06^{\prime} 40.3^{\prime \prime} \mathrm{E}$ ) and Biała Rawska (orchard B; $51^{\circ} 52^{\prime} 00.2^{\prime \prime} \mathrm{N}, 20^{\circ} 31^{\prime} 10.0^{\prime \prime} \mathrm{E}$ ) near Skierniewice; Trzylatków (orchard C; $51^{\circ} 47^{\prime} 50.9^{\prime \prime} \mathrm{N}, 20^{\circ} 42^{\prime} 03.4^{\prime \prime} \mathrm{E}$ ) near Grójec; and Zawada (orchard D; 50 $48^{\prime} 35.2^{\prime \prime} \mathrm{N}$, $19^{\circ} 19^{\prime} 20.9^{\prime \prime}$ E) near Częstochowa) protected according to Integrated Pest Management (IPM) rules, but without any pre-harvest applications against storage diseases. Apples of cv. "Ligol" were evaluated during 6 storage seasons (10 trials), "Gala" during 4 seasons (7 trials), "Golden Delicious" during 3 seasons (3 trials), and "Gloster" during 2 seasons (2 trials). From each location, 1000 fruits from central parts of canopies were harvested at stage $\mathrm{BBCH} 87$ (fruits ripe for picking) and their maturity was determined on the basis of a starch test. They were stored in the experimental cold room of The National Institute of Horticultural Research in Skierniewice, at a temperature of $2{ }^{\circ} \mathrm{C}$ and relative air humidity of $90-92 \%$. The sample of each variety amounted to 1000 apples (4 crates of 250 ). Storage was finished when the apples reached the conditions of consumption maturity. Depending on the variety, the number of healthy and infected apples was assessed after 5-7 months.

\subsection{Diagnostics of Apple Storage Diseases}

After storage, symptomatic apples were counted and the results are presented as disease incidence, that is, the percent of fruits displaying symptoms of a particular disease, per cultivar and per orchard.

Diseases were diagnosed on the basis of their macroscopic symptoms (size and look of rot, color, smell, presence of mycelium and spores). In the case when etiological signs of the disease were absent, the fruits were examined for the identification of a causal agent. The surface of symptomatic fruits was disinfected by rinsing with ethanol $70 \%$, the peel was locally removed, and a piece of flesh fruit was taken from the margin of healthy and rotten tissue and transferred onto a Petri dish with PDA medium (Difco Laboratories, Sparks, MD, USA). After 7 days of incubation at $20 \pm 1^{\circ} \mathrm{C}$, the fungal species were preliminary determined based on morphological features. Based on the appearance of the colonies, and the shape and size of the spores, the species were determined using available keys [23]. When this evaluation was not sufficient for identification, a molecular approach was applied. From fungal mycelium, DNA extractions using a GeneMATRIX Plant \& Fungi DNA Purification Kit (EURx, Gdańsk, Poland) were made following the 
manufacturer's instructions and concentrations of obtained nucleic acids were measured using a NanoDrop 1000 spectrophotometer. The DNA was used as a matrix in PCRs with species-specific primers: CaInt2 [24] and ITS4 [25], specific for Colletotrichum acutatum sensu lato, in multiplex PCR with species specific primers for Neofabraea spp. [19], or in PCR with primers universal for fungi ITS1 and ITS4 [25]. The concentrations of components and thermal profiles of PCRs were applied as proposed by the authors of the primer sets. The products of the PCR with ITS1/ITS4 set were sequenced. Sequencing was performed by GENOMED SA (Warszawa, Poland), as the commercial service, then obtained sequence data were used as a query in the GenBank sequence database.

Results of identification obtained for each disease are expressed in percentage of infected fruits in comparison to all stored in a sample.

\section{Results and Discussion}

Research carried out during six storage seasons showed a very high variation in the incidence of diseases of apples of biotic origin depending on the season, apple cultivar, and location of the orchard. Apples of the same variety, stored in the same conditions during the season, but from different orchards, were affected to different degrees. For example, on apples of the cv. "Ligol" from orchard A in the 2012/2013 season, total rot equaled 5.5\%, whereas on apples from orchard B, rot was three times higher $(16.9 \%$, Table 1$)$. Similarly, in the 2013/2014 season, among "Gala" apples, 59.1\% of fruits were rotted from orchard (C), whereas only $12.8 \%$ were rotted from orchard (A). This is probably due to different the phytosanitary status of these orchards, because some of the fungi causing apple diseases are also pathogens of bark and wood, or occur as saprotrophs in apple tree crowns as a source of apple infection [14]. Analysis of the type of disease on apples of the examined cultivars showed that the most common disease was bull's eye rot, and results from 217 multiplex PCRs indicated the presence of $N$. vagabunda as the causal agent. Disease incidence varied from 0.4 to $55.8 \%$ depending on the cultivar, season, and location of the orchard. In particular, the highest level of infection of fruits was observed on apples cv. "Gala" and "Ligol" which, in the 2013/2014 season, amounted to 55.8\% and 33.3\%, respectively. In contrast, the lowest infestation, regardless of the cultivar and orchard location, was observed in the 2012/2013 season (0.4-5.7\%). Bull's eye rot has also been indicated by many authors in several reports as an important disease of apples [11-17].

The second most-frequent disease was gray mold (Botrytis cinerea Pers.). The incidence of the disease on cvs. "Ligol", "Golden Delicious", "Gala", and "Gloster" was an average level and amounted to $3.2 \%, 1.8 \%, 2.4 \%$, and $4.4 \%$, respectively (Table 1 ). Gray mold is considered to be one of the most important post-harvest diseases of various fruits and vegetables, including apples [26]. Infection occurs via damage to the apple skin or as a result of latent infection. Before placing apples in cold storage there are no symptoms, which only develop during storage [27].

The third most-common disease was blue mold of apples (Penicillium expansum Link), for which disease incidence ranged from 0.2 to $3.4 \%$ (Table 1). This is a typical disease of stored apples, which develops at the site of skin damage and its incidence depends primarily on the quality of the apple skin and the presence of damage. Careful harvesting and effective fruit protection against pests help reduce the occurrence of the disease in commercial orchards [28]. Nonetheless, Penicillium species can be important pathogens of stored apples in some growing regions such as Romania and Greece [29,30].

The lowest disease incidence, not exceeding 1\%, was for brown rot of apples caused by Monilinia spp. (Table 1). Very few fruits with symptoms were observed within each batch of 1000 apples; hence, disease incidence did not exceed $1 \%$ at each study site. This is congruent with previous studies confirming a negligible contribution of this disease in apple rot $[9,31]$. In contrast, Ivic et al. [2] found that, on "Idared" apples in Serbia, brown rot was the dominant disease, causing losses averaging $3.1 \%$. 
In addition to the diseases mentioned above, which have been described in Poland in the past $[9,31]$, new diseases were detected, such as alternariosis caused by Alternaria spp., and fruit rots caused by Colletotrichum spp. and Neonectria ditissima (Table 1).

Table 1. Intensity of post-harvest diseases in years 2012-2018.

\begin{tabular}{|c|c|c|c|c|c|c|c|c|}
\hline \multirow{2}{*}{$\begin{array}{l}\text { Storage } \\
\text { Season } \\
\text { Orchard }\end{array}$} & \multicolumn{8}{|c|}{$\%$ of Apples with Disease Syptoms after Storage } \\
\hline & Total & $\begin{array}{c}\text { Bull's Eye Rot } \\
\text { Neofabraea } \\
\text { spp. }\end{array}$ & $\begin{array}{c}\text { Bitter Rot } \\
\text { (anthracnose) } \\
\text { Colletotrichum } \\
\text { spp. }\end{array}$ & $\begin{array}{c}\text { Gray Mold } \\
\text { Botrytis } \\
\text { cinerea }\end{array}$ & $\begin{array}{l}\text { Brown Rot } \\
\text { Monilinia } \\
\text { fructigena }\end{array}$ & $\begin{array}{l}\text { Blue Mold } \\
\text { Penicillium } \\
\text { expansum }\end{array}$ & $\begin{array}{c}\text { Alternariosis } \\
\text { Alternaria } \\
\text { spp. }\end{array}$ & $\begin{array}{c}\text { Rot Caused } \\
\text { by } \\
\text { Neonectria } \\
\text { ditissima }\end{array}$ \\
\hline \multicolumn{9}{|c|}{ "Ligol" } \\
\hline \multicolumn{9}{|l|}{$2012 / 2013$} \\
\hline Orchard A & 5.5 & 2.7 & 0 & 0.1 & 0.2 & 1.8 & 0.7 & 0 \\
\hline Orchard B & 16.9 & 5.7 & 0 & 6.9 & 0.2 & 3.1 & 1.0 & 0 \\
\hline \multicolumn{9}{|l|}{$2013 / 2014$} \\
\hline Orchard A & 41.3 & 33.3 & 0.4 & 5.4 & 0 & 1.0 & 0.9 & 0.3 \\
\hline Orchard B & 20.6 & 17.2 & 0.2 & 2.3 & 0 & 0.5 & 0.2 & 0.2 \\
\hline \multicolumn{9}{|l|}{$2014 / 2015$} \\
\hline Orchard A & 22.2 & 10.0 & 4.2 & 5.0 & 0 & 1.7 & 1.1 & 0.2 \\
\hline Orchard B & 3.0 & 0.6 & 0.1 & 1.2 & 0.1 & 0.2 & 0.6 & 0.2 \\
\hline Orchard D & 7.0 & 3.4 & 0 & 2.8 & 0 & 0.3 & 0 & 0.5 \\
\hline \multicolumn{9}{|l|}{$2015 / 2016$} \\
\hline Orchard A & 12.8 & 5.6 & 0.1 & 2.8 & 0.2 & 1.9 & 2.2 & 0 \\
\hline Orchard D & 5.9 & 2.7 & 0 & 2.0 & 0.1 & 0.5 & 0.6 & 0 \\
\hline \multicolumn{9}{|l|}{$2016 / 2017$} \\
\hline Orchard A & 9.7 & 2.5 & 1.5 & 3.5 & 0.3 & 1.5 & 0.4 & 0 \\
\hline \multicolumn{9}{|c|}{ "Golden Delicious" } \\
\hline \multicolumn{8}{|l|}{$2012 / 2013$} & 0 \\
\hline $\begin{array}{l}2013 / 2014 \\
\text { Orchard A }\end{array}$ & 13.2 & 10.6 & 0.1 & 1.3 & 0 & 1.1 & 0.1 & 0 \\
\hline \multicolumn{9}{|l|}{$2016 / 2017$} \\
\hline \multicolumn{9}{|c|}{ "Gala" } \\
\hline \multicolumn{9}{|l|}{$2013 / 2014$} \\
\hline Orchard A & 12.8 & 11.7 & 0.1 & 0.5 & 0 & 0.3 & 0 & 0.2 \\
\hline Orchard C & 59.1 & 55.8 & 0 & 2.2 & 0.5 & 0.5 & 0 & 0.1 \\
\hline \multicolumn{9}{|l|}{$2015 / 2016$} \\
\hline \multicolumn{9}{|l|}{$2016 / 2017$} \\
\hline Orchard C & 19.8 & 13.2 & 0.3 & 5.1 & 0.4 & 0.7 & 0 & 0.1 \\
\hline Orchard C & 13.8 & 4.7 & 0 & 5.1 & 0.4 & 3.4 & 0 & 0.2 \\
\hline \multicolumn{9}{|l|}{$2017 / 2018$} \\
\hline Orchard A & 42.0 & 38.8 & 0 & 1.3 & 0 & 1.9 & 0 & 0 \\
\hline Orchard B & 25.2 & 23.6 & 0 & 0.03 & 0 & 1.6 & 0 & 0 \\
\hline \multicolumn{9}{|c|}{ "Gloster" } \\
\hline $\begin{array}{l}2012 / 2013 \\
\text { Orchard A }\end{array}$ & 8.7 & 0.4 & 0 & 6.8 & 0.1 & 1.4 & 0 & 0 \\
\hline $\begin{array}{l}2013 / 2014 \\
\text { Orchard A }\end{array}$ & 9.6 & 5.9 & 0 & 2.0 & 0 & 1.4 & 0 & 0.3 \\
\hline
\end{tabular}

Alternariosis of apples, caused by fungi of Alternaria spp., occurred only on apple cvs. "Ligol" and "Golden Delicious", with a low incidence, averaging $0.8 \%$ and $0.2 \%$, respectively (Table 1). Fungi of the Alternaria species are usually considered to be secondary apple pathogens that develop on previously damaged fruit tissue. They infect via skin damage, punctures caused by insects, and fruits with symptoms of various physiological changes [5]. The symptoms of alternariosis observed in these studies were in the form of 
deep and extensive rot with irregular edges and dark-brown color. In the fruit cross-section, the rotting pulp also had brown-black discoloration [32].

Previous research has shown that apple rot caused by Colletotrichum spp. has been sporadic in Poland, possibly because of its similar symptomatology with bull's eye rot disease [33]. The first symptom observations occurred in the 1990s and the causal agent was believed to be the fungus Glomerella cingulata (anamorph Colletotrichum gloeosporioides), according to Sutton and Shane [34]. Due to the more frequent occurrence of the disease, especially since 2009, etiological studies have been undertaken, which showed that the disease is caused by the fungus Glomerella acutata (Colletotrichum acutatum), and a distinct disease called apple and pear anthracnosis was identified [35], which is similar to the existing name in the English literature for diseases caused by the fungi from the genus Colletotrichum spp. (anthracnose or bitter rot). In the current study, anthracnose disease incidence was at a low level (0-1.5\%, Table 1). Only in one case (2014/2015 season, "Ligol") was incidence higher, amounting to $4.2 \%$. All 74 isolates of Colletotrichum spp. obtained from rotting apples were determined on the basis of a positive PCR reaction with CaInt2 and ITS4 primers. Recent taxonomic studies have identified 31 clades within Colletotrichum spp. [36], and their precise attribution to this species is based on DNA sequence analysis of five regions, in addition to ITS. According to this classification, the strains identified in our research can be included in the fungal complex, described as Colletotrichum acutatum sensu lato-a complex species in contrast to Colletotrichum acutatum sensu stricto.

Peres et al. [20] and Giraud [12] also reported the growing importance of anthracnose on apples in other European countries. This is thought to be related to global warming in Europe $[37,38]$. The initial symptoms of apple anthracnose are very similar to those of bull's eye rot. They are small, round, brown lesions developing around the lenticels. After transferring the apples to a higher temperature, the spots grow very quickly, and they sometimes merge and are covered with very small acervuli, which release orange-pink masses of fungal spores.

This study also suggests that Neonectria ditissima is a new pathogen of stored apples in Poland. The incidence of the disease was low $(0-0.5 \%$, Table 1$)$. The fungus $N$. ditissima, previous name $N$. galligena, has been known for many years as an agent of fruit tree canker, and rarely as an apple fruit pathogen. Berrie (1989) stated that, in 1980 in England, the apples losses of cv. "Cox's Orange Pippin" amounted to $0.2-4.2 \%$ due to this disease [39]. There is a clear relationship between the occurrence of fruit tree canker in the orchard and the incidence of apple rot caused by the same pathogen in the cold room; after the canker epidemic in the region of Lower Elbe in Germany, very strong apple rot in cold storage caused by N. ditissima was observed [40]. N. ditissima on apples during storage has been reported in Romania with varying incidence depending on the cultivar [29]. Since canker of fruit trees is widespread in Poland on many apple varieties, an increased occurrence of apple rot caused by Neonectria ditissima in the coming years may be expected. Symptoms of the disease include brown, slightly depressed rot spots that form mainly around the calyx, although they can also be present anywhere on the fruit. On the surface of the spots, white and beige mycelia with spores develop. A characteristic feature of this rot is the easy separation of the rotting flesh from the healthy tissue. Completely rotten apples can infect neighboring fruits by contact, which leads to nest rot, as in the case of gray mold.

During the current studies, the symptoms of a new disease were noticed on several apples. Fungal mycelia did not develop on the surface, even when the apple was completely rotted, and in the stalk cavity a sticky liquid appeared. Similar symptoms have been described by Snowdon [5] as Phomopsis rot. After isolation and molecular identification (GenBank Acc. nos. of the ITS rDNA region: MT478098-101), the fungus was identified as Diaporthe eres. For the first time this pathogen was found on stored apples in 2018 in our country [41].

After determining the type and incidence of storage diseases, the incidence of each disease on individual apple varieties was analyzed. It was found that the bull's eye rot of apples represented the largest group among all diseases on apples of three varieties, "Gala", 
"Ligol", and "Golden Delicious" and equaled 82.0\%, 57.8\%, and 50.0\%, respectively. By comparison, on the "Gloster" apples, gray mold (48.1\%) was the predominant disease, and bitter rot accounted for $34.4 \%$ of all diseases (Figure 1). However, it should be noted that the subject of the study comprised only two samples of "Gloster" apples. Among the new diseases, anthracnose was most common on "Ligol" (4.5\%) and "Golden Delicious" (2.0\%); rot caused by Neonectria ditissima was most common on "Gloster" $(1.7 \%)$; and alternariosis was most common on "Ligol" (5.3\%) and "Golden Delicious" (2.0\%). Diaporthe eres was isolated from four apples of the cv. "Gala" and three "Golden Delicious" apples.
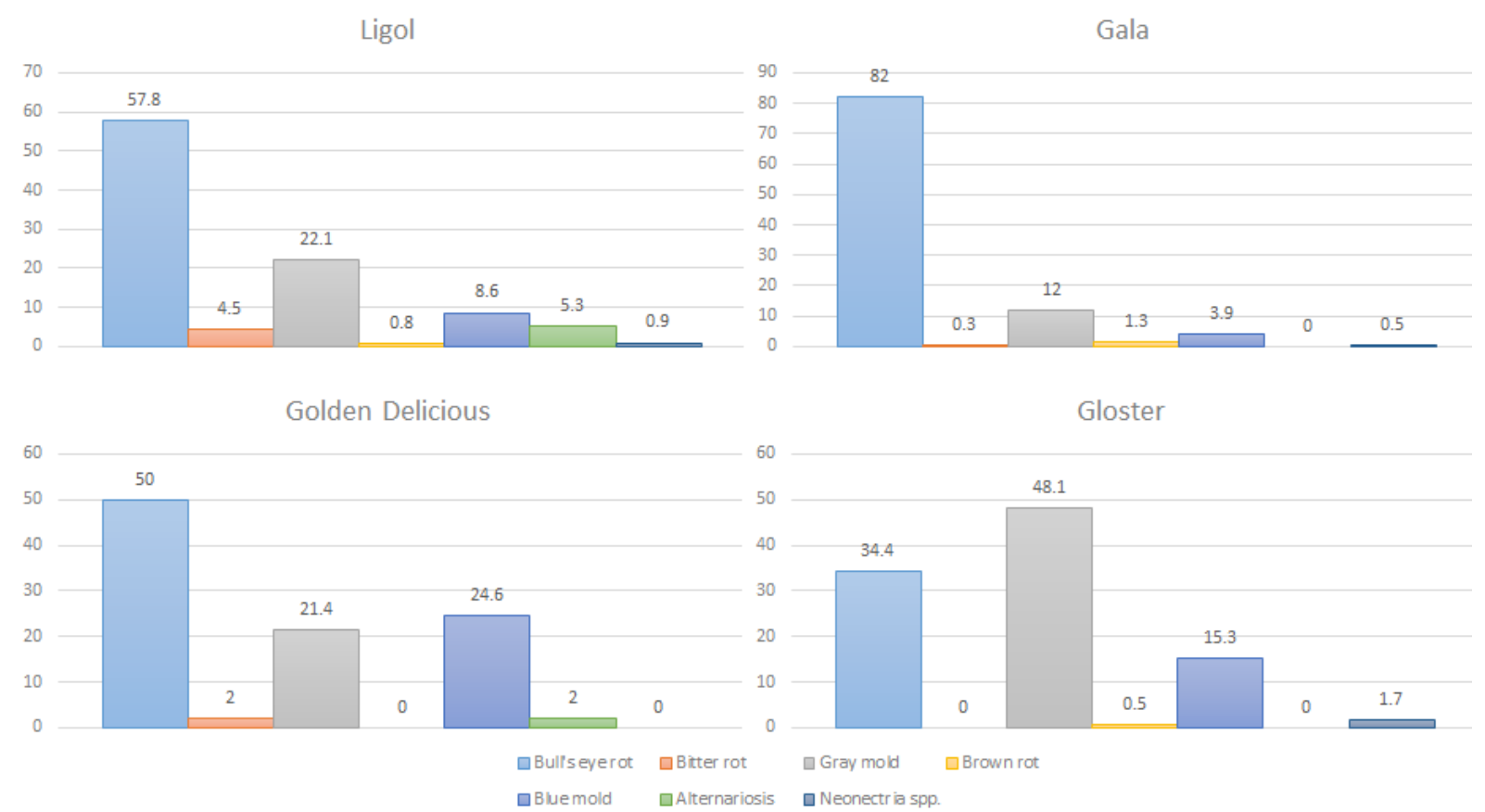

Figure 1. Share of diseases on cvs. "Ligol", "Gala", "Golden Delicious", and "Gloster".

\section{Conclusions}

The research carried out during six storage seasons showed that storage diseases occurred during each year of the study, and their frequency varied widely and differed between apple cultivars, and between the same cultivars grown in different locations. The most frequently observed diseases were bull's eye rot, gray mold, and blue mold of apples. Diseases such as brown rot, alternariosis, anthracnosis, and rot caused by Neonetria ditissima occurred at lower intensities. All the orchards included in this study were located in the same climatic zone. The incidence of each disease resulted from natural infections. Moreover, during storage of apples in 2018, rot caused by Diaporthe eres was observed for the first time. A clear identification of emerging, post-harvest pathogens of apples is critical for disease management and for anticipating future outbreaks.

Author Contributions: Conceptualization, methodology, writing—original draft preparation, investigation, formal analysis, visualization H.G.; methodology, investigation, validation, writing-original draft preparation, data curation, supervision H.B.; resources, writing-original draft preparation M.M.; writing-review and editing, supervision J.P. All authors have read and agreed to the published version of the manuscript.

Funding: This research received no external funding.

Institutional Review Board Statement: Not applicable.

Informed Consent Statement: Not applicable.

Data Availability Statement: Not applicable.

Acknowledgments: Not applicable. 
Conflicts of Interest: The authors declare no conflict of interest.

\section{References}

1. Neri, F.; Gualanduzzi, S.; Brigati, S. Effect of harvest maturity on quality, physiological and pathological disorders during storage of 'Gala' apples. Acta Hort. 2005, 682, 2069-2076. [CrossRef]

2. Ivić, D.; Sever, Z.; Miličević, T. Estimation of economic loss due to postharvest diseases of apple (cv. Idared) during four seasons. Pomol. Croat. 2012, 18, 51-62.

3. Aguilar, C.G.; Mazzola, M.; Xiao, C.L. Timing of apple fruit infection by Neofabraea perennans and Neofabraea kienholzii in relation to bull's-eye rot development in stored apple fruit. Plant Dis. 2017, 101, 800-806. [CrossRef]

4. Jones, A.L.; Aldwinckle, H.S. Compendium of Apple and Pear Diseases; APS Press the American Phytopathological Society: St. Paul, MN, USA, 1997; p. 100.

5. Snowdon, A.L. A Colour Atlas of Post-Harvest Diseases and Disorders of Fruits and Vegetables. Vol. 1: General Introduction and Fruits; Wolf Scientific Ltd.: London, UK, 1990; pp. 170-218.

6. Blažek, J.; Kloutvorová, J.; Křelinová, J. Incidence of storage diseases on apples of selected cultivars and advanced selections grown with and without fungicide treatments. Hort. Sci. 2006, 33, 87-94. [CrossRef]

7. Rejman, A. Studia nad przechowywaniem 12 odmian jabłek. Roczniki Nauk Rolniczych 1954, 69, 349-383.

8. Borecka, H. Cryptosporiopsis malicorticis (Zeller et Childs) Wollenw. syn. Gloeosporium perennans Zeller et Childs, jako czynnik chorobotwórczy na jabłkach w okresie przechowywania. Acta Agrobot. 1962, 12, 11-66.

9. Bryk, H.; Bartosiewicz, B.; Rejnus, M. Nasilenie chorób grzybowych na przechowywanych jabłkach w latach 1993-1995. In Proceedings of the Materiały Ogólnopolskiej Konferencji Ochrony Roślin Sadowniczych, Skierniewice, Poland, 20-21 February 1996; pp. 134-135.

10. Bryk, H.; Wojtas-Kozieł, B.; Lewandowska, M.; Rejnus, M. Grzyby powodujące choroby podczas przechowywania oraz ocena skuteczności fungicydów w zwalczaniu tych chorób. Pr. Inst. Sad. Kwiac. Ser. A 1991, 30, 127-135.

11. Weber, R. Apple storage rots: The situation in Northern Germany. In Proceedings of the COST 864 Expert Meeting, Bergen, Norway, 25-26 March 2009.

12. Giraud, M. Fungal storage diseases of apple in France. In Proceedings of the COST 864 Expert Meeting, Bergen, Norway, 25-26 March 2009.

13. Neri, F.; Mari, M.; Brigati, S.; Bertolini, P. Control of Neofabraea alba by plant volatile compounds and hot water. Postharvest Biol. Technol. 2009, 51, 425-430. [CrossRef]

14. Henriquez, J.L.; Sugar, D.; Spotts, R.A. Etiology of bull's eye rot of pear caused by Neofabraea spp. in Oregon, Washington, and California. Plant Dis. 2004, 88, 1134-1138. [CrossRef]

15. De Jong, S.N.; Levesque, C.E.; Verkley, G.J.M.; Abeln, E.C.A.; Rahe, J.E.; Braun, P.G. Phylogenetic relationships among Neofabraea species causing tree cankers and bull's-eye-rot of apple based on DNA sequencing of ITS nuclear rDNA, mitochondrial rDNA, and the ß-tubulin gene. Mycol. Res. 2001, 105, 658-669. [CrossRef]

16. Soto-Alvear, S.; Lolas, M.; Rosales, I.M.; Chavez, E.R.; Latorre, B.A. Characterization of the bull's eye rot of apple in Chile. Plant Dis. 2013, 97, 485-490. [CrossRef] [PubMed]

17. Cunnington, J.H. Three Neofabraea species on pome fruit in Australia. Australas. Plant Pathol. 2004, 33, 453-454. [CrossRef]

18. Cameldi, I.; Neri, F.; Menghini, M.; Pirondi, A.; Nanni, I.M.; Collina, M.; Mari, M. Characterization of Neofabraea vagabunda isolates causing apple bull's eye rot in Italy (Emilia-Romagna region). Plant Pathol. 2017, 66, 1432-1444. [CrossRef]

19. Michalecka, M.; Bryk, H.; Poniatowska, A.; Puławska, J. Identification of Neofabraea species causing bull's eye rot of apples in Poland and their direct detection in apple fruit using multiplex PCR. Plant Pathol. 2016, 65, 643-654. [CrossRef]

20. Peres, N.A.; Timmer, L.w.; Adaskaveg, J.E.; Correl, J.C. Lifestyles of Colletotrichum acutatum. Plant Dis. 2005, 89, 784-796. [CrossRef] [PubMed]

21. Wenneker, M.; Pham, K.; Kohl, J. Postharvest diseases of pome fruit and sources of inokulum in orchard in The Netherlands. Agropecu. Catarin. 2018, 31, 57-63.

22. Xiao, C.L.; Kim, Y.K. Postharvest fruit rots in apples caused by Botrytis cinerea, Phacidiopycnis washingtonensis, and Sphaeropsis pyriputrescens. Plant Health Prog. 2008, 9, 34. [CrossRef]

23. Marcinkowska, J. Oznaczanie Rodzajów Grzybów Ważnych w Patologii Roślin; Fundacja "Rozwój SGGW": Warszawa, Poland, 2003; p. 328. ISBN 8372740569.

24. Sreenivasaprasad, S.; Sharada, K.; Brown, A.É.; Mills, P.R. PCR-based detection of Colletotrichum acutatum on strawberry. Plant Pathol. 1996, 45, 650-655. [CrossRef]

25. White, T.J.; Bruns, T.; Lee, S.; Taylor, J. Amplification and Direct Sequencing of Fungal Ribosomal RNA Sequencing of Fungal Ribosomal RNA Genes for Phylogenetics. In Book: PCR Protocols: A Guide to Methods and Applications; Innis, M.A., Gelfand, D.H., Sninsky, J.J., White, T.J., Eds.; Academic Press: San Diego, CA, USA, 1990; pp. 315-322.

26. Romanazzi, G.; Smilanick, J.L.; Feliziani, E.; Droby, S. Integrated management of postharvest gray mold on fruit crops. Postharvest Biol. Technol. 2016, 113, 69-76. [CrossRef]

27. Munoz, C.; Sanz, M.I. Detection transposable elements in Botrytis cinerea in latent infection stage from symptomless apples. J. Coast. Life Med. 2014, 2, 125-131.

28. Wenneker, M.; Kohl, J. Postharvest decay of apples and pears in the Netherlands. Acta Hort. 2014, 1053, 107-111. [CrossRef] 
29. Florian, V.C.; Puia, C.; Groza, R.; Suciu, L.A.; Florian, T. Study of the major pathogens that lead to apple fruit decay during storage. Not. Bot. Horti Agrobot. 2018, 46, 538-545. [CrossRef]

30. Konstantinou, S.; Karaoglanidis, G.S.; Bardas, G.A.; Minas, I.S.; Doukas, E.; Markoglou, A.N. Postharvest fruit rots of apple in Greece: Pathogen incidence and relationships between fruit quality parameters, cultivar susceptibility, and patulin production. Plant Dis. 2011, 95, 666-672. [CrossRef] [PubMed]

31. Bryk, H. Choroby przechowalnicze jabłek i gruszek. In Proceedings of the Materiały VI Międzynarodowych Targów Agrotechniki Sadowniczej, Warszawa, Poland, 15-16 January 2010; pp. 17-26.

32. Jurick, W.M., II; Gaskins, V.L.; Luo, Y.G. First report of Alternaria alternata causing postharvest decay on apple fruit during cold storage in Pensylvannia. Plant Dis. 2014, 98, 690. [CrossRef]

33. Borecki, Z. Badania nad gorzką zgnilizną jabłek powodowaną przez grzyby Gloeosporium perennans Zeller et Childs, Gloeosporium album Osterw. I Gloeosporium fructigenum Berk. Acta Agrobot. 1961, 10, 53-97. [CrossRef]

34. Sutton, T.B.; Shane, W.W. Epidemiology of the perfect stage of Glomerella cingulata on apples. Phytopathology 1983, 73, 1179-1183. [CrossRef]

35. Bryk, H.; Michalecka, M.; Jakubowska, A. Grzyby z rodzaju Colletotrichum—Sprawcy gorzkiej zgnilizny jabłek. In Proceedings of the Materiały 54 Ogólnopolskiej. Konferencji Ochrony Roślin Sadowniczych, Ossa k. Białej Rawskiej, Poland, 23-24 February 2011; pp. 108-110.

36. Damm, U.; Cannon, P.F.; Woudenberg, J.H.C.; Crous, P.W. The Colletotrichum acutatum species complex. Stud. Mycol. 2012, 73, 37-113. [CrossRef]

37. Cattiaux, J.; Vautard, R.; Cassou, C.; Yiou, P.; Masson-Delmotte, V.; Codron, F. Winter 2010 in Europe: A cold extreme in a warming climate. Geophys. Res. Lett. 2010, 37, L20704. [CrossRef]

38. West, J.S.; Townsend, J.A.; Stevens, M.; Fitt, B.D.L. Comparative biology of different plant pathogens to estimate effects of climate change on crop diseases in Europe. Eur. J. Plant Pathol. 2012, 133, 315-331. [CrossRef]

39. Berrie, A.M. Storage rots of apple and pear in South East England 1980-1988: Incidence and fungicide resistance. IOBC Bull. 1989, 12, 229-239.

40. Weber, R.W.S. Biology and control of the apple canker fungus Neonectria ditissima (syn. N. galligena) from a Northwestern European perspective. Erwerbs-Obstbau 2014, 56, 95-107. [CrossRef]

41. Głos, H.; Bryk, H.; Michalecka, M.; Poniatowska, A.; Puławska, J. First report of Diaporthe eres, a new pathogen causing rot of apples during storage period in Poland. J. Plant Pathol. 2021, 103, 393-394. [CrossRef] 